\title{
Changes in the character of glaciomarine sedimentation in the southwestern Weddell Sea, Antarctica: evidence from the core PS1423-2
}

\author{
Kevin CRAWFORD, \\ School of Biological and Earth Sciences, Liverpool John Moores University, Byrom Street, Liverpool L3 3AF, England \\ Gerhard KuhN, \\ Alfred-Wegener-Institut für Polar- und Meeresforschung, Postfach 120161, 27515 Bremerhaven, Germany \\ Michael J. Hambrey \\ School of Biological and Earlh Sciences, Liverpool John Moores University, Byrom Street, Liverpool L3 3AF, England
}

\begin{abstract}
Investigations of the stratigraphy and facies within a $2.69 \mathrm{~m}$ long gravity core (PS1423-2) from the southwestern Weddell Sea, Antarctica, indicate a significant change in the character of glaciomarine sedimentation since grounded ice withdrew from the continental shelf. Based on visual description, X-radiography, clast shape, particle-size analysis, physical properties and geochemical data, the core used in this analysis comprises five distinct units, from top to bottom: (i) massive diamicton, (ii) weakly to well-stratified diamicton, (iii) millimetre-scale laminated muds, with little or no coarse-clastic input, (iv) well- to weakly stratified diamicton, (v) massive diamicton. This succession is attributed to the variation in sedimentation associated with the recession of the grounding line of a previously advanced glacier. Grounded ice decoupled from the continental shelf to form an ice shelf, probably initiated by a rise in sea level in response to global climatic changes. Following disintegration of the ice shelf, sedimentation was influenced by marked variations in iceberg production. AMSderived ${ }^{14} \mathrm{C}$ ages from the upper $46 \mathrm{~cm}$ of the core indicate that the succession has been deposited since the end of the most recent glacial maximum (late Pleistocene), a conclusion supported by published data.
\end{abstract}

\section{INTRODUCTION}

Glaciomarine sediments range from deep-sea sediments with a low content of ice-rafted detritus through to deposits formed at the grounding line of a glacier ending in the sea (Elverhoi and Roaldset, 1983). Detailed investigations of glaciomarine facies can lead to an understanding of processes and environments of deposition, and allow development of integrated models of sediment deposition and reconstruction of the glacial history of particular depositional settings.

The objectives of this study are to examine processes which occurred in, and to deduce the depositional history of, an area of the southwestern Weddell Sea through the detailed study of a relatively short $(2.69 \mathrm{~m})$ gravity core. This core was logged and facies, clast and particle-size analyses undertaken. Physical-property, geochemical and $\mathrm{X}$-radiography data were also obtained.

The core (PS1423-2) was obtained at $74^{\circ} 42.1^{\prime} \mathrm{S}$, $61^{\circ} 19.2^{\prime} \mathrm{W}$ in a water depth of $476 \mathrm{~m}$ (Fig. 1) during the 1986 Antarktis IV/3 expedition, aboard the research vessel Polarstern (Fütterer, 1987). The site is in the
Weddell Sea, near Cape Fiske, in a region perennially covered by sea ice. The location is of particular interest as it represents an area influenced by ice drainage from two sources: the Antarctic Peninsula to the west, and the West Antarctic ice sheet via the Filchner-Ronne Ice Shelf.

Shelf sediments in the Weddell Sea have been investigated in several previous studies (Haase, 1986; Fütterer and Melles, 1990; Melles, 1991). Each of these studies has described contemporary glaciomarine sediments in close proximity to core PS1423-2. Other studies have documented the sedimentology, facies distribution and processes of glaciomarine sedimentation in other parts of the continental shelf of Antarctica (e.g. Anderson and others, 1980, 1991; Domack, 1982; Elverhoi and Roaldset, 1983; Elverhøi, 1984).

\section{METHODS}

Following core description, sediment slices were prepared for X-radiography $(27.5 \times 10 \times 1 \mathrm{~cm})$ to view fine-scale details not observed during core-logging. Once the slices 


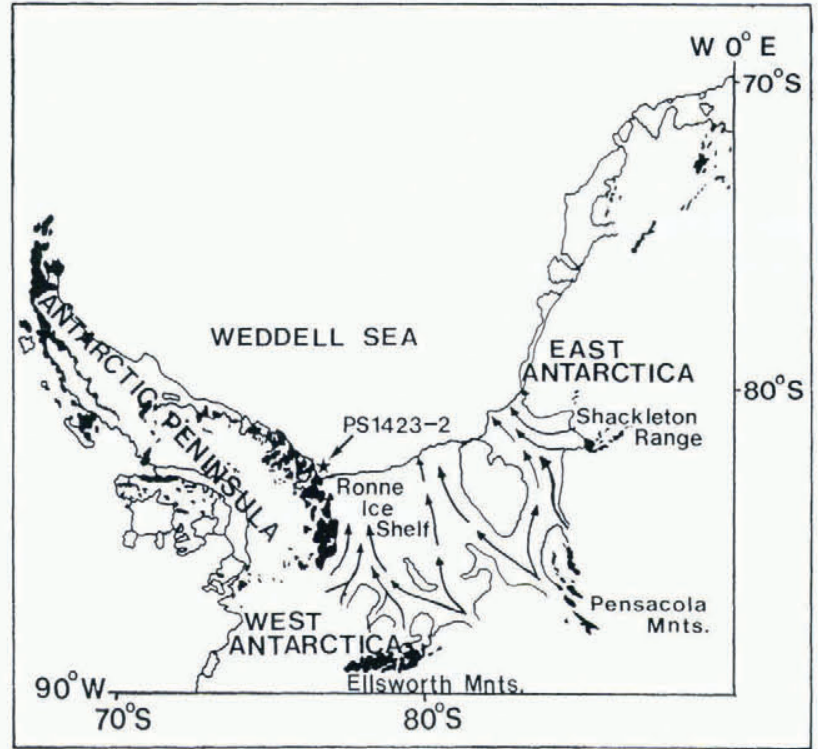

Fig. 1. Location map showing the position of core PS14232 within the Weddell Sea embayment, and the close proximity of the site to the Antarctic Peninsula. Ice flowlines are indicated. Black areas identify scallered outcrops. (After Smith and O'Connell, 1990.)

were removed, samples for sedimentological analyses were taken from the core at an average spacing of $10 \mathrm{~cm}$. About $5 \mathrm{~cm}^{3}$ were taken for physical-property determinations (i.e. porosity, wet bulk density, carbonate and organic carbon content), $5 \mathrm{~cm}^{3}$ for particle-size distribution (siltand clay-sized fractions) and $70 \mathrm{~cm}^{3}$ for coarse-fraction analysis (gravel- and sand-sized fractions).

The fine-particle-size sample $(<63 \mu \mathrm{m})$ was wetsieved, centrifuged and dried at $40^{\circ} \mathrm{C}$. A known weight was then resuspended in a $0.1 \%$ solution of Calgon (sodium hexametaphosphate). The silt and clay distributions were determined using a SediGraph 5000D Particle Size Analyzer.

The $70 \mathrm{~cm}^{3}$ coarse-fraction sample $(>63 \mu \mathrm{m})$ was wetsieved, dried at $60^{\circ} \mathrm{C}$ and dry-sieved into individual whole phi-size fractions following the standard sieving technique. Particle-size distribution was determined on material $<2 \mathrm{~mm}$ in size through the combination of the sand-, siltand clay-sized fraction data.

The remaining gravel $(>2 \mathrm{~mm})$ was studied for clastshape analysis, 25 or 50 gravel-sized clasts being analyzed for shape depending on the number available. Roundness (Powers, 1953) of each clast was estimated visually, and the clasts measured to determine sphericity Krumbein, 1941). Roundness vs sphericity plots were constructed and compared with those of Boulton (1978) and particularly with data from the glaciomarine environment of Antarctica (Domack and others, 1980; Kuhn and others, 1993), to give an indication of the transport pathways followed by debris within a glacier system. Lithologies of the gravel clasts and the clast surface features were also noted.

Sedimentary units were initially defined on the basis of visual description and $\mathrm{X}$-radiographs. The variables used included textural grading, presence or absence of stratification and other sedimentary structures, gravel content and particle-size distribution.

\section{CORE DESCRIPTION}

The visual descriptions, facies associations, data interpretation and $\mathrm{X}$-radiography identified five stratigraphic units (Fig. 2) within the core:

Unit I $(0-50 \mathrm{~cm})$. Massive diamicton, a non-stratified sandy mud or muddy silty sand with 5-30\% gravel clasts.

Unit II $(50-75 \mathrm{~cm})$. Weakly stratified to well-stratified diamicton, similar to unit I but with wispy stratification.

Unit III $(75-87 \mathrm{~cm})$. Millimetre-scale laminated muds, regular alternations of thin (millimetre-scale) light and dark material, probably representing silt-rich and silt-poor mud layers, with little or no coarse-clastic input.

Unit IV $(87-126 \mathrm{~cm})$. Well-stratified to weakly stratified diamicton, similar to unit II.

Unit $V(126-269 \mathrm{~cm})$. Massive diamicton, similar to unit I but with 10-20\% gravel clasts.

The majority $(>99 \%)$ of the clasts within the core are dark-grey/black mudstones, sandstones, volcaniclastics and light-coloured, fine-grained felsites. These limited lithologies indicate that the main source area could be a sequence of middle- to upper-Jurassic volcaniclastic

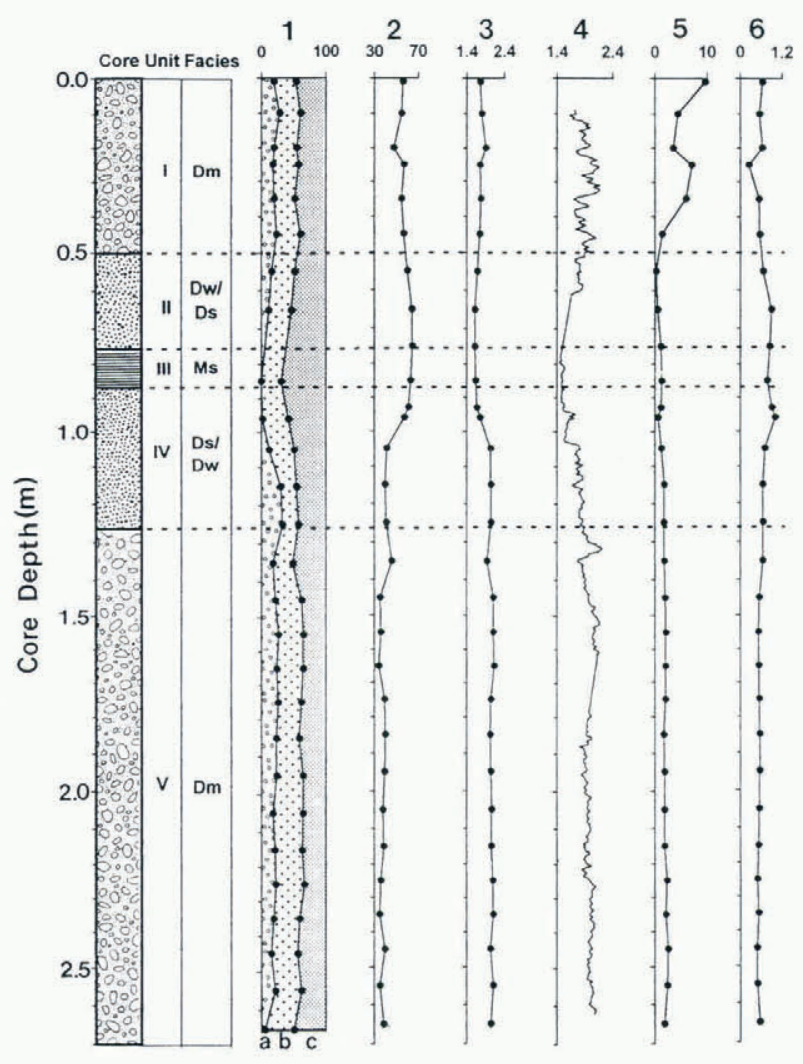

Fig. 2. Composite log showing core unil divisions, facies and the following data. 1, grain-size distribution (\%): a, sand, $b$, sill, $c$, clay; 2, porosity (\%); 3, wet bulk density $\left(\mathrm{kg} \mathrm{m}^{-3}\right) ; 4$, gamma-ray attemuation density $\left(\mathrm{kg} \mathrm{m}^{-3}\right) ; 5$, carbonate content $(\%)$; and 6 , organic carbon content $(\%)$. Unit divisions as outlined in text. Facies: Dm, massive diamicton; Dw, weakly stratified diamicton; Ds, well-stratified diamicton; Ms, stratified mud. 
shales, siltstones and sandstones containing intrusions of Early Cretaceous plutons from the southern Antarctic Peninsula (Hinze and others, 1987).

\section{Unit descriptions}

Unit $I$ is characterised by a variable texture, dominated by silt and clay, with a sand content of $18-28 \%$ (Fig. 2). The gravel content typically ranges from $5 \%$ to $30 \%$, with concentrations rising to $50 \%$ and $60 \%$ at 6 and $24 \mathrm{~cm}$, respectively. X-radiography reveals that this unit is massive and that the upper few centimetres is bioturbated. Roundness vs sphericity plots of the unit reveal subangular, angular and very angular shapes (Fig. 3a and b), suggesting a supraglacial source for the gravel fraction.

Biogenic material, including whole and fragmentary bryozoans, barnacles, bivalves, gastropods and echinoid spines, was observed only within the upper $45 \mathrm{~cm}$ and comprises the only macrofossils found within the core. Accelerator mass spectrometer (AMS) ${ }^{14} \mathrm{C}$ dating of this biogenic material at depths of 22-25 and $42-46 \mathrm{~cm}$ gives corrected ages of $2250 \pm 80 \mathrm{BP}$ and $4910 \pm 95 \mathrm{BP}$, respectively (Hedges and others, 1995).

Sedimentation rates based on the AMS-derived ages give values of $0.104 \mathrm{~mm} \mathrm{a}^{1}$ for the interval 0 to $22-25 \mathrm{~cm}$, and $0.077 \mathrm{~mm} \mathrm{a}^{-1}$ for the interval $22-25$ to $42-46 \mathrm{~cm}$.

Unit II is similar to unit I but less texturally variable (Fig. 2). Silt- and clay-sized fractions are dominant, with less sand than in unit $\mathrm{I}$. The sand content increases from $<1 \%$ at the base to $16 \%$ at the top of the unit. The gravel content follows the same trend, ranging from $<1 \%$ at the base to $10 \%$ at the top of the unit. The base of unit II is composed principally of silt and clay, with minor amounts of sand and gravel. X-radiography indicates that this unit is matrix-supported, with most clasts being less than $10 \mathrm{~mm}$ long. The top of the unit, from 50 to $69 \mathrm{~cm}$, appears to be weakly stratified, with clasts concentrated in layers. The base is more stratified, with two finingupwards sequences within the intervals 69-72 and 72$75 \mathrm{~cm}$. Roundness vs sphericity plots (Fig. 3c) exhibit a supraglacial debris signature similar to that in unit I.

Unit III comprises material predominantly of silt and clay size, with little or no material greater than $63 \mu \mathrm{m}$ (Fig. 2). X-radiography reveals a clast-free laminated mud with $2-3 \mathrm{~mm}$ scale alternations of X-ray dark and light material.

Unit $I V$ is similar to unit II. Silt- and clay-sized fractions are dominant but decrease from $98 \%$ at the top to $67 \%$ at the base (Fig. 2). The sand component is variable and ranges from $2 \%$ at the top to $33 \%$ at the base. The gravel content also varies, from $<1 \%$ at the top to $30 \%$ at the base. X-radiography reveals significant sedimentary features including several fining-upward sequences of coarser layers, with large clasts up to $18 \mathrm{~mm}$ long (87$114 \mathrm{~cm}$ ) interbedded with relatively clast-free laminated muds. The interval $114-126 \mathrm{~cm}$ is a weakly stratified diamicton and consists of a mix of clasts, up to $10 \mathrm{~mm}$ long, and matrix with no mud laminae. Roundness vs sphericity plots exhibit a mixed supraglacial and basal debris source for the gravel clasts (Fig. 3d-f).

Unit $V$ is texturally homogeneous, with a fairly uniform sediment composition (Fig. 2). Silt- and claysized fractions are dominant, as in the previous units, and there is very little variation in the sand component $(20$ $27 \%$ ) throughout. Gravel content ranges from $10 \%$ to $20 \%$. X-radiography reveals no sedimentary structures and a uniform composition of clasts (up to $10 \mathrm{~mm}$ long) and matrix. Roundness vs sphericity plots exhibit a mixed
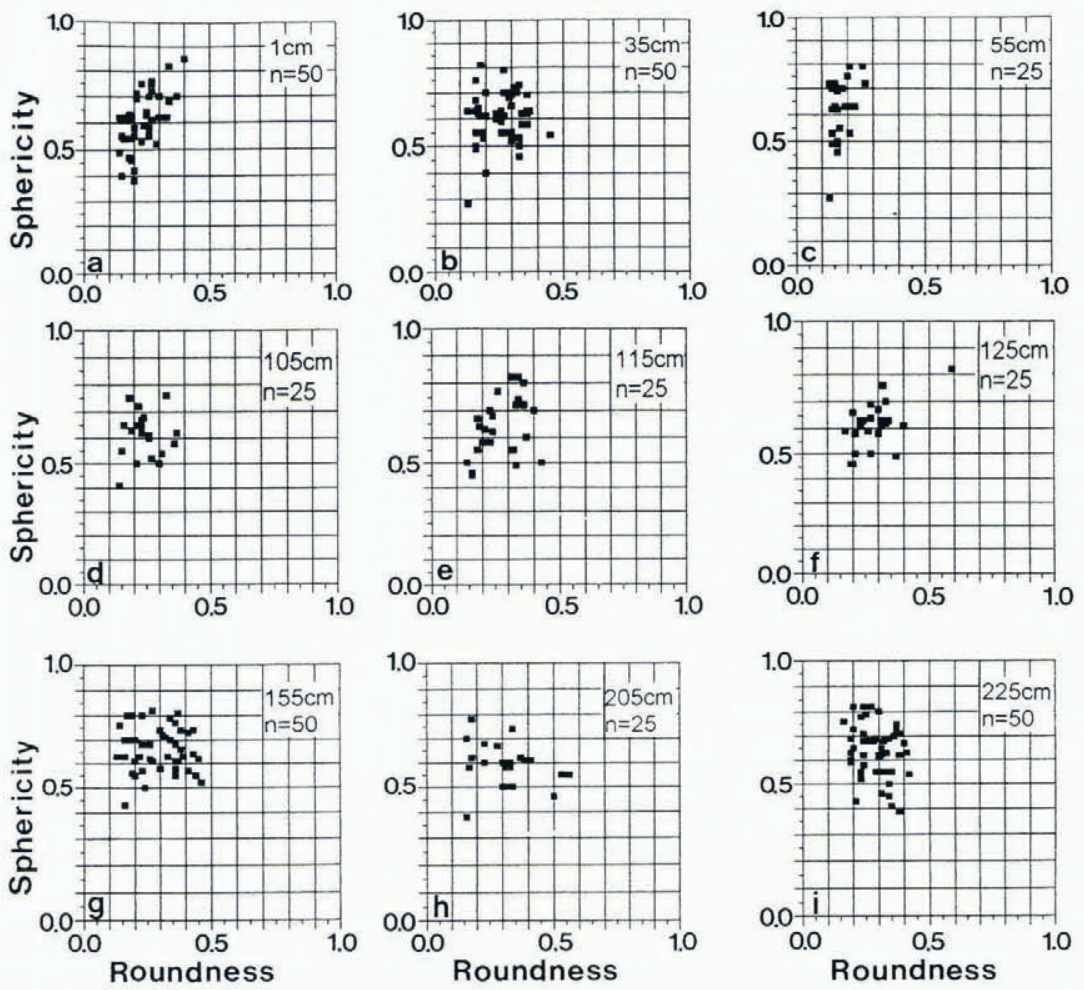

Fig. 3. Roundness vs sphericity plots for some intervals within units $I(a, b), I I(c), I V(d, e, f)$ and $V(g, h, i)$. Roundness values: $0.12-0.17$, very angular; 0.17-0.25, angular; $0.25-0.35$, subangular; $0.35-0.49$, subrounded; 0.49 0.70, rounded; 0.70-1.0, well-rounded. (From Powers, 1953.) 
basal debris and supraglacial source (Fig. $3 \mathrm{~g}-\mathrm{i}$ ), with perhaps a tendency towards a basal debris source for the gravel clasts.

\section{Physical-property data}

Physical-property data are shown in the composite $\log$ in Figure 2. Each of the properties measured can be observed to vary throughout the core and correlate well to the different units. Continuous measurement of density by gamma-ray attenuation provides a more comprehensive density data set and gives a much clearer indication of density changes in the core than individual sampling.

\section{INTERPRETATION OF UNITS AND DEPOSITIONAL ENVIRONMENT}

The lower massive diamicton (unit V) appears texturally homogeneous. The roundness vs sphericity data suggest that most of the debris in this unit is derived from sediment-rich basal ice, with minor amounts of debris from the subaerial environment.

Kuhn and others (1993) attempted to apply the concepts of the debris-transport pathway study undertaken by Boulton (1978) on temperate and sub-polar glaciers to the glaciomarine environment of Antarctica and the cold thermal regime of Antarctic glaciers and ice sheets. They concluded that pathways followed by debris within Antarctic glaciers and ice sheets under a polar thermal regime could be identified. Also, through comparison with onshore sediments they determined that the gravel component was largely derived from the base of the ice sheet, which tends to have higher angularity and sphericity than the gravel sampled from temperate and sub-polar glaciers by Boulton (1978). Our data for unit $\mathrm{V}$ may show this higher degree of angularity. Physical properties and particle-size distribution (Fig. 2) are relatively constant throughout unit $\mathrm{V}$ and indicate a constant depositional environment.

Our roundness vs sphericity data indicate that unit V has the character of basal glacial debris. It can be classified as a basal till as defined by Anderson and others (1980) and Domack and others (1980). More specifically, it was probably deposited as lodgement till on the basis of the relatively low porosity that indicates consolidation by an ice mass.

The upper massive diamicton (unit I) is similar to unit $\mathrm{V}$ but texturally different. The roundness vs sphericity data indicate that most of the debris is derived from the subaerial environment. The gravel clasts appear to have a more supraglacial character on the basis of their angular nature. Kuhn and others (1993) suggested that the higher degree of clast angularity in the cold polar regime of Antarctica may be the result of fracturing, crushing and erosion of bedrock in preference to basal sliding and abrasion. Basal transport of angular clasts cannot be ruled out. However, the limited data presented here probably reflect a true supraglacial source for the debris, considering the close proximity of the core site to valley glaciers from the Antarctic Peninsula (Fig. 1). The variations in particle-size distribution could be the result of a fluctuating source for the deposition of clastic material, such as iceberg-rafting. Physical-property and geochemical data from this unit are relatively variable (Fig. 2). Porosity tends to be high by comparison with unit V, signifying the non-consolidated nature of this diamicton. Both density measurements exhibit significant variations and may be attributable to variations in the debris content within the unit. The rise in carbonate is probably accounted for by the presence of carbonate-shelled macrofossils. These fossils and evidence of bioturbation suggest periods of non-deposition or reduced accumulation rates with relatively little coarse-clastic input, facilitating colonisation of the sediment substrate.

Dowdeswell and others (1994) interpreted massive diamictons from the East Greenland shelf as having formed predominantly from the rafting of sediments in icebergs and subsequent release of the debris by melting. Holocene sedimentation rates, modelled as part of their study, vary from 0.1 to $0.3 \mathrm{~m} \mathrm{ka}^{\text {' }}$, and are suggested to be compatible with rates of iceberg-rafting of sediment. This mechanism could account for the deposition of unit I, with the lower sedimentation rates $\left(77-104 \mathrm{~mm} \mathrm{ka}^{-1}\right)$ from our data reflecting the polar regime of Antarctica, resulting in a slower melting-out of debris. An alternative mechanism (Anderson and others, 1980, 1991) suggests that this diamicton may represent a "compound glacial marine sediment" where there is co-deposition of glacial material derived from ice-rafting and marine sediments. These types of sediments have been widely identified from the Antarctic continental shelf (e.g. Anderson and others, 1980, 1991; Domack, 1982; Elverhøi, 1984; Haase, 1986; Fütterer and Melles, 1990; Melles, 1991). Both mechanisms have ice-rafting as a significant process, and variations in the ice-rafting process would produce variations in the amount of coarse-clastic material being deposited. Given the strong angular (supraglacial) nature of the clasts and the lithologies in unit I, we suggest they are derived from icebergs calving from valley glaciers on the Antarctic Peninsula during the mid- to late Holocene.

The laminated muds (unit III) have little or no coarse-clastic input and exhibit regular millimetre-scale laminae. Physical-property and geochemical data (Fig. 2) are consistent throughout, indicating that a uniform depositional process was active for the whole interval. The porosity maximum within this unit suggests that the mud is probably the result of suspension settling that results in a higher water content and porosity. The low density measurements and increased organic carbon content reflect the lack of coarse-clastic deposition.

Domack (1990) indicated that laminated muds in the region of the Antarctic Peninsula can be found on the continental slope, forming in open marine conditions and on the continental shelf beneath floating ice. Rhythmic units lacking in bioturbation and in ice-rafted debris are inferred by Domack (1990) to represent marine deposition beneath floating ice possibly under the influence of tidal processes. The present data on the laminated unit (III) may support such inference. The lack of coarseclastic debris in unit III may be attributed to the basal freeze-on of saline ice preventing direct deposition from debris-rich basal ice, or the basal ice not being debrisrich. We interpret these laminated muds as having been deposited beneath an expanded Filchner-Ronne Ice Shelf or, more likely, given the clast-provenance information, 
under an expanded ice shelf originating from valley glaciers on the Antarctic Peninsula.

The stratified diamictons (units II and IV) are texturally similar to units III and I, and V and III, respectively. The physical and geochemical properties (Fig. 2) of both are variable but intermediate between the diamictons (units I and $\mathrm{V}$ ) and the laminated muds (unit III).

Unit IV has a variable particle-size distribution, with the sediment texture gradational between units $\mathrm{V}$ and III. Clast shapes reveal a mixed supraglacial and basal debris source and we suggest that this unit represents an intermediate water-lain deposit formed as the grounding line retreated and an ice shelf developed. The influence of water in the depositional process is inferred from the presence of stratification.

Unit II has a variable particle-size distribution, with the sediment texture gradational between units III and I. Stratification occurs at the base of unit II and decreases towards the top of the unit. The top of the unit displays the supraglacial debris-source signature like unit I. We suggest that unit II may represent another intermediate water-lain sediment formed as the ice shelf disintegrated to leave an area influenced by ice-rafted material and marine sedimentation (unit I).

\section{GONGLUSIONS}

Several conclusions can be reached from this detailed investigation of a short core obtained from the southwestern Weddell Sea.

(1) The sequence of sediments observed in the cored interval reflects the variation in sedimentary processes associated with the recession of the grounding line of a formerly larger glacier to form an ice shelf. Subsequent disintegration of this ice shelf resulted in the fluctuations of the ice-cover and iceberg production.

(2) Most of the shelf ice over the site originated from the southern end of the Antarctic Peninsula, indicated by the provenance of the clastic debris.

(3) The upper diamicton has been deposited since the end of the Last Glacial Maximum, inferred from the AMS-derived radiocarbon dates of $2250 \pm 80 \mathrm{BP}$ and $4910 \pm 95 \mathrm{BP}$.

(4) The lower diamicton, an overconsolidated diamicton, by analogy with Anderson and others (1991), was deposited during the Last Glacial Maximum (late Pleistocene).

(5) The stratified diamictons and laminated muds were deposited under an ice shelf following the Last Glacial Maximum, assumed by their position between the lower, presumed late-Pleistocene diamicton and the upper, Holocene-dated diamicton.

\section{AGKNOWLEDGEMENTS}

We are grateful to the officers and crew of the RV Polarstern for their help in the collecting of the core. K.C. wishes to thank the Alfred-Wegener-Institut for access to the core and for the use of its facilities whilst undertaking the sampling. The receipt of a research studentship from the former Polytechnic and College Funding Council and Liverpool John Moores University is acknowledged by K.C. This is contribution No. 986 of the Alfred-WegenerInstitut für Polar- und Meeresforschung.

\section{REFERENCES}

Anderson, J. B., D. D. Kurtz, E. W. Domack and K. M. Balshaw. 1980. Glacial and glacial marine sediments of the Antarctic continental shelf. \%. Geol., 88 4), 399-414.

Anderson, J. B., D. S. Kennedy, M.J. Smith and E. W. Domack. 1991. Sedimentary facies associated with Antarctica's floating ice masses. In Anderson, J. B. and G. M. Ashley, eds. Glacial marine sedimentation; paleoclimatic significance. Boulder, CO, Geological Society of America, 1-25. (GSA Special Paper 261.)

Boulton, G.S. 1978. Boulder shapes and grain-size distributions as indicators of transport paths through a glacier and till genesis. Sedimentology, 25 (6), $773-799$.

Domack, E. W. 1982. Sedimentology of glacial and glacial marine deposits on the George V-Adélie continental shelf, East Antarctica. Boreas, 11 (1), 79-97.

Domack, E.W. 1990. Laminated terrigenous sediments from the Antarctic Peninsula: the role of subglacial and marine processes. In Dowdeswell, J.A. and J. D. Scourse, eds. Glacimarine environments: processes and sediments. London, Geological Society, 91-103. (Special Publication 53.

Domack, E. W.. J. B. Anderson and D. D. Kurtz. 1980. Clast shape as an indicator of transport and depositional mechanisms in glacial marine sediments: George V continental shelf, Antarctica. J. Sediment. Petrol., 50 3 , $813-820$.

Dowdeswell, J.A., R.J. Whittington and P. Marienfeld. 1994. The origin of massive diamicton facies by iceberg rafting and scouring, Scoresby Sund, East Greenland. Sedimentology, 41 (1), 21-3.5.

Elverhoi, A. 1984. Glacigenic and associated marine sediments in the Weddell Sea, fjords of Spitsbergen and the Barents Sea: a review. Mar. Geol., 57 (1-4), 53-88.

Elverhoi, A. and E. Roaldset. 1983. Glaciomarine sediments and suspended particulate matter, Weddell Sea Shelf, Antarctica. Polar Res., 1 (1), 1-21.

Fütterer, D. K., ed. 1987. The Expedition ANTARKTIS-IV of RV “Polarstern" 1985/86: report of legs ANT-IV/3-4. Ber. Polarforsch. 33.

Fütterer, D. K. and M. Melles. 1990. Sediment patterns in the southern Weddell Sea: Filchner Shelf and Filchner Depression. In Bleil, U. and J. Thiede, eds. Geological history of the polar oceans: Arctic versus Antarctic. Dordrecht, etc., Kluwer Academic Publishers, 381 401. (NATO ASI Series C: Mathematical and Physical Sciences 308. )

Haase, G. M. 1986. Glaciomarine sediments along the Filchner/Ronne Ice Shelf, southern Weddell Sea. First results of the 1983/84 Antarktis-2/4 Expedition. Mar. Geol., 72 (3-4), 241-258.

Hedges, R. E. M., R. A. Housley, C. B. Ramsey and G.J.van Klinken. 1995. Radiocarbon dates from the Oxford AMS system: archaeometry datelist 19. Archaeometry, 37, 195-214.

Hinze, K., Y. Kristoffersen and German-N.W.S.S. Group. 1987. Antarctica - recent advances in the understanding of the continental shelf. Geol. Jahrb., Ser. E, 37, 3-54.

Krumbein, W.C. 1941. Measurement and geological significance of shape and roundness of sedimentary particles. 7. Sediment. Petrol., $112), 64-72$.

Kuhn, G., M. Melles, W. U. Ehrmann, M.J. Hambrey and G. Schmiedl. 1993. Character of clasts in glaciomarine sediments as an indicator of transport and depositional processes, Weddell and Lazarev Seas, Antarctica. J. Sediment. Petrol., 63 3), 477-487.

Melles, M. 1991. Paläoglaziologie und Paläozeanographic im Spätquartär am Kontinentalrand des südlichen Weddellmeeres, Antarktis. Ber. Polarforsch. 81.

Powers, M. C. 1953. A new roundness scale for sedimentary particles. $\mathcal{J}$. Sediment. Petrol., 23 2), 117-119.

Smith, C. H. and S. B. O'Connell. 1990. Provenance and glacial history of very fine quartz sand from the Weddell Sea, Antarctica. Proceedings of the Ocean Drilling Program. Scientific Results, 113, 89109. 